\title{
Lymphocyte subset abnormalities, autoantibodies and their relationship with HLA DR types in children with Type 1 (insulin-dependent) diabetes and their first degree relatives
}

\author{
M.Peakman', T. Warnock ${ }^{1}$, A. Vats ${ }^{1}$, G.L.McNab ${ }^{1}$, J.Underhill ${ }^{2}$, P.T. Donaldson ${ }^{2}$, D. Vergani ${ }^{1}$ \\ ${ }^{1}$ Department of Immunology, King's College School of Medicine and Dentistry, London, UK \\ ${ }^{2}$ Institute of Liver Studies, King's College School of Medicine and Dentistry, London, UK
}

Summary Type 1 (insulin-dependent) diabetes mellitus is associated with abnormalities of circulating lymphocyte subsets and autoantibodies. To investigate the prevalence of these in non-diabetic siblings and nondiabetic parents of children with Type 1 diabetes, we analysed T-cell subsets of function and activation in 31 families with an index case of Type 1 diabetes and related these to autoantibodies and HLA DR type. Using two and three colour cytofluorimetry, we studied total and activated (HLA-DR + ) $\mathrm{CD3}+, \mathrm{CD} 4+$, CD8 + lymphocytes and on CD4 + lymphocytes the CD45RA/RO "naive" and "memory" cell phenotypes. Diabetic children (mean duration of disease 3.1 years) had a reduced total lymphocyte count $(p<0.05)$, their non-diabetic siblings a reduced CD4 + T-helper cell count $(p<0.05)$, and their parents a reduced percentage and number of CD3 + T cells $(p<0.01$ and $p<0.05$ ) compared with age-matched control subjects. Diabetic children, their siblings and parents all had significantly increased levels of activated CD4 + T-helper cells $(p<0.01, p<0.05$ and $p<0.01)$. In diabetic chil- dren and their siblings there was a significant over-expression of the CD45RO "memory" cell marker and significant under-expression of the CD45RA "naive" cell marker, whilst these were normal in the parents. Islet cell antibody positive diabetic children had significantly higher levels of CD45RO-expressing CD4+ lymphocytes than those who were islet cell antibody negative $(p<0.05)$. Amongst the siblings and parents, possession of HLA-DR4 was associated with lower percentages of $\mathrm{CD} 4+$ and higher percentages of CD8 + T cells. These findings extend current knowledge about the role of immunoregulatory CD45RA/ $R O$ cells in Type 1 diabetes. In addition, they demonstrate lymphocyte subset abnormalities in unaffected family members, some of which may be influenced by HLA DR alleles. [Diabetologia (1994) 37: 155-165]

Key words T-cell activation, T-cell memory, CD45 isoforms, HLA DR types, first degree relatives of diabetic patients.
Type 1 (insulin-dependent) diabetes mellitus results from the destruction of islet beta cells in the pancreas, and the finding of a T-lymphocyte infiltrate in the islets both at diagnosis [1] of the disease and following recurrent diabetes in pancreatic iso-grafts [2] supports the contention that the disease is immune-mediated [3]. Further evidence of a role for the immune system in

Received: 1 March 1993 and in final revised form: 16 August 1993

Corresponding author: Dr. M. Peakman, Department of Immunology, King's College School of Medicine and Dentistry, London SE5 9PJ, UK beta-cell damage derives from the finding at diagnosis of autoantibodies [4] and alterations in lymphocyte subsets in the peripheral blood, including elevated levels of activated T cells [5], CD5 + B lymphocytes [6] and CD45RA + ("naive") CD4 + and CD8 + lymphocytes $[7,8]$.

There is a strong genetic component in susceptibility to the development of Type 1 diabetes, a large proportion of which maps to the MHC class II region on chromosome 6 [9]. The protein products of this region, the heterodimeric surface molecules HLA-DR, -DP and -DQ, present peptide antigens to $T$ lymphocytes. One explanation of their role in susceptibility to diabetes is that class II molecules have a critical role in presenting 
beta-cell autoantigens to autoreactive $\mathrm{T}$ lymphocytes in the islets of Langerhans. Arguing against this mechanism is the fact that the highest risk of Type 1 diabetes is associated with alleles at the DQ locus [10,11], yet the vast majority of autoreactive T-cell clones generated from patients with autoimmune diseases such as Type 1 diabetes are restricted to autoantigens presented not by HLA-DQ molecules, but by HLADR [12-14]. For this reason, alternative explanations for HLA-associated susceptibility are being sought [15]. One possibility is that class II alleles, originally known as the "immune response" genes, influence the reactivity of individuals to an immune stimulus.

To characterise cellular and humoral immune abnormalities in first degree relatives of Type 1 diabetic children, we studied lymphocyte subsets of function and activation in families with an index case of Type 1 diabetes. In addition, families were HLA typed, to examine whether cellular immune abnormalities segregate with particular HLA DR alleles.

\section{Subjects, materials and methods}

We studied 31 families, all with a single index case of Type 1 diabetes attending the District Diabetes Centre, Farnborough Hospital, Kent. All families with children attending the Diabetes Centre were approached and all those willing to participate were recruited. Ethical permission for this study was obtained from the Farnborough Hospital Ethical Committee and all participants gave their informed consent. In 8 families, samples were obtained from both parents and 2 siblings; in 12 families from both parents and one sibling; in 4 families from both parents only; in the remainder, samples were obtained from the mother and 3 siblings $(n=1), 2$ siblings $(n=1)$, one sibling $(n=1)$ or no siblings $(n=3)$; in one family, samples were obtained from the father and index case only.

There were a total of 31 children with Type 1 diabetes (14 males, mean age $\pm S D ; 10.8 \pm 4.5$ years) with a mean duration of diabetes of $3.1 \pm 1.5$ years. Duration of diabetes ranged from 3 months to 5 years, and 3 diabetic children were studied within 1 year of diagnosis. Type 1 diabetes was defined in accordance with the guidelines of the National Diabetes Data Group [16] requiring insulin to prevent diabetic ketoacidosis and sustain life, and at diagnosis, all had elevated blood glucose and glycosuria. At the time of sampling, mean random blood glucose level amongst the diabetic children was $11.9 \pm 5.5 \mathrm{mmol} / \mathrm{l}$ and the mean level of haemoglobin $\mathrm{A}_{1 \mathrm{c}}\left(\mathrm{HbA}_{\mathrm{lc}}\right)$ amongst the diabetic children was $10.1 \pm 1.8 \%$. In addition, we studied 55 parents, ( 25 males, age $39.1 \pm 7.0$ years) and 34 siblings (15 males, mean age $12.8 \pm 4.3$ years), none of whom had diabetes (mean $\pm \mathrm{SD}$ level of $\mathrm{HbA}_{1 \mathrm{c}} 6.8 \% \pm 0.7$ in the siblings and $6.7 \% \pm 0.7$ in the parents). As control subjects, blood was obtained from 25 healthy adults ( 11 males, age $35.4 \pm 6.6$ years) recruited from the staff of King's College Hospital and 25 healthy children (12 males, age $11.4 \pm 3.8$ years) who were recruited by the Medway and Gillingham Branch (Kent) of the Children's Liver Disease Foundation (CHILD). None of the control subjects had a family history of Type 1 diabetes. Blood was drawn from control subjects during the same period and at the same time of day as for the study group to avoid biases resulting from seasonal, diurnal, or technical variations. Samples were only obtained from individuals without symptoms or clinical evidence of infection.
Blood was taken into bactericidal-free heparin $(10 \mathrm{U} / \mathrm{ml})$, $10 \mathrm{mmol} / \mathrm{l}$ EDTA or allowed to clot at room temperature for $30 \mathrm{~min}$. Serum was separated from clotted blood by centrifugation at $1500 \mathrm{~g}$, aliquoted and stored $-70^{\circ} \mathrm{C}$.

\section{Lysed whole blood immunofluorescence staining of lymphocytes}

To restrict the effects of day-to-day variability on the measurement of lymphocyte subsets, the majority of the study group (26 of 31 families) and all subjects in the control groups were bled en masse and the analyses performed on four single days. Lymphocyte subsets were identified by two and three colour immunofluorescence staining using a lysed whole blood technique as previously described $[7,17,18]$. The monoclonal antibody combinations used and the populations identified are shown in Table 1. Analysis of stained lymphocytes was carried out using an aircooled, single argon laser, bench-top flow cytometer (FACScan; Becton Dickinson, Oxford, UK). Data were acquired on between 5,000 and 10,000 cells and stored in list mode. Fluorescence data were acquired in logarithmic mode over five log decades. Non-specific binding of monoclonal antibodies was assessed using isotype- and fluorochrome-matched monoclonal antibodies directed against an irrelevant target (anti-keyhole limpet haemocyanin, Becton Dickinson) and was subtracted from all results. All data acquisition and analysis was performed by a single operator unaware of the source of the samples. Inter- and intra-assay coefficients of variation established using 10 consecutive determinations on a single day and on a cryopreserved sample of peripheral blood mononuclear cells over several days were less than $6 \%$ and less than $10 \%$, respectively.

Total $(\mathrm{CD} 3+) \mathrm{T}$ lymphocytes are expressed as a percentage of the total lymphocytes; CD4 + and CD8 + T lymphocytes as a percentage of total T cells; activated cells as a percentage of the $\mathrm{CD} 3+, \mathrm{CD} 4+$ and CD8 + populations; CD45R subsets as a percentage of the $\mathrm{CD} 4+$ population; TCR $\gamma \delta+\mathrm{T}$ lymphocytes as a percentage of the CD3 + T-lymphocyte population; and CD5 + B lymphocytes as a percentage of the CD20 + B-cell population. Absolute numbers of lymphocyte subsets were derived from leucocyte counts and lymphocyte differentials performed on a Coulter Stacker (Coulter, Hialeah, Fla., USA).

\section{HLA typing}

Class II HLA DR typing was carried using restriction fragment length polymorphism (RFLP) analysis as previously described [19]. HLA-DRB gene polymorphisms were identified using a $517 \mathrm{bp}$ PStI fragment of the exon-specific HLA-DRB cDNA clone pRTv1 (kindly supplied by Dr. J.Bidwell, UK Transplant Centre, Bristol, UK). HLA-DRB allogenotypes were identified from the hybridization patterns visualised by autoradiography [20-22].

\section{Detection of autoantibodies}

Islet cell cytoplasmic antibodies (ICA) were detected in a twostep indirect immunofluorescence assay as previously described [23] on unfixed 5- $\mu \mathrm{m}$ cryostat sections of blood group 0 human pancreas. This assay was tested in the stage III Immunology and Diabetes Workshop in ICA proficiency, performing with 100\% specificity, a detection limit of 5 Juvenile Diabetes Foundation 
Table 1. Combinations of monoclonal antibodies used in two- and three-colour immunofluorescence staining of peripheral blood mononuclear cells and the lymphocyte populations identified

\begin{tabular}{|c|c|c|c|}
\hline \multicolumn{4}{|c|}{ Targets and labels of monoclonal antibodies: } \\
\hline Fluorescein & Phycoerythrin & Biotin & Populations identified \\
\hline CD3 & CD4 & & Helper/inducer T lymphocytes \\
\hline CD3 & CD8 & & Suppressor/cytotoxic T lymphocytes \\
\hline CD3 & HLA-DR & & Activated T lymphocytes \\
\hline CD4 & HLA-DR & & Activated helper/inducer T lymphocytes \\
\hline CD8 & HLA-DR & & Activated suppressor/cytotoxic T lymphocytes \\
\hline CD45RO & $\mathrm{CD}_{45 \mathrm{RA}^{\mathrm{b}}}$ & CD4 & Naive/memory helper/inducer T lymphocytes \\
\hline TCR- $\gamma \delta$ & CD3 & & TCR- $\gamma \delta+$ T lymphocytes \\
\hline CD20 & CD5 & & CD5 + B lymphocytes (B-1 cells) \\
\hline
\end{tabular}

Note: All monoclonal antibodies obtained from Becton Dickinson (Oxford, UK) with the exception of those from ${ }^{\text {a }}$ Dako (High Wycombe, UK) and ${ }^{\mathrm{b}}$ Coulter Electronics (Luton, UK)

Table 2. Mean (SD) absolute numbers and percentages of total lymphocytes, CD3 +, CD4 + and CD $8+$ T-lymphocyte subsets, the CD4: CD8 ratio and the percentage of each subset which is activated (HLA-DR + ) in patients with Type 1 diabetes, their parents, siblings and control subjects

\begin{tabular}{|c|c|c|c|c|c|}
\hline & Normal children & $\begin{array}{l}\text { Type } 1 \text { diabetic } \\
\text { children }\end{array}$ & $\begin{array}{l}\text { Siblings of diabetic } \\
\text { children }\end{array}$ & $\begin{array}{l}\text { Adult control } \\
\text { subjects }\end{array}$ & $\begin{array}{l}\text { Parents of dia- } \\
\text { betic children }\end{array}$ \\
\hline $\begin{array}{l}\text { Total lymphocytes } \\
\left(\times 10^{6} \text { per } \mathrm{ml}\right)\end{array}$ & $\begin{array}{c}3.3 \\
(1.0)\end{array}$ & $\begin{array}{r}2.7^{a} \\
(1.1)\end{array}$ & $\begin{array}{c}2.8 \\
(1.1)\end{array}$ & $\begin{array}{l}2.5 \\
(0.6)\end{array}$ & $\begin{array}{c}2.3 \\
(0.7)\end{array}$ \\
\hline $\begin{array}{l}\text { CD3 + T } \\
\text { lymphocytes (per } \mu l)\end{array}$ & $\begin{array}{l}2097 \\
(650)\end{array}$ & $\begin{array}{l}1725 \\
(820)\end{array}$ & $\begin{array}{l}1780 \\
(799)\end{array}$ & $\begin{array}{l}1757 \\
(385)\end{array}$ & $\begin{array}{l}1495^{\mathrm{a}} \\
(491)\end{array}$ \\
\hline $\begin{array}{l}\mathrm{CD} 3+\mathrm{T} \\
\text { lymphocytes }(\%)\end{array}$ & $\begin{array}{l}64.5 \\
(7.1)\end{array}$ & $\begin{array}{l}63.5 \\
(8.1)\end{array}$ & $\begin{array}{l}63.7 \\
(6.0)\end{array}$ & $\begin{array}{l}70.3 \\
(5.4)\end{array}$ & $\begin{array}{l}65.5^{\mathrm{b}} \\
(6.9)\end{array}$ \\
\hline $\begin{array}{l}\text { CD4 + T } \\
\text { lymphocytes }(\text { per } \mu \mathrm{l})\end{array}$ & $\begin{array}{l}1183 \\
(481)\end{array}$ & $\begin{array}{c}970 \\
(404)\end{array}$ & $\begin{array}{r}949^{a} \\
(348)\end{array}$ & $\begin{array}{l}1080 \\
(305)\end{array}$ & $\begin{array}{c}894 \\
(352)\end{array}$ \\
\hline $\begin{array}{l}\mathrm{CD} 4+\mathrm{T} \\
\text { lymphocytes (\%) }\end{array}$ & $\begin{array}{l}55.7 \\
(6.9)\end{array}$ & $\begin{array}{l}57.8 \\
(5.9)\end{array}$ & $\begin{array}{l}54.4 \\
(7.7)\end{array}$ & $\begin{array}{l}61.5 \\
(8.7)\end{array}$ & $\begin{array}{c}59.4 \\
(10.1)\end{array}$ \\
\hline $\begin{array}{l}\text { CD } 8+T \\
\text { lymphocytes }(\text { per } \mu l)\end{array}$ & $\begin{array}{l}755 \\
(228)\end{array}$ & $\begin{array}{c}676 \\
(431)\end{array}$ & $\begin{array}{c}720 \\
(419)\end{array}$ & $\begin{array}{c}587 \\
(196)\end{array}$ & $\begin{array}{c}570 \\
(223)\end{array}$ \\
\hline $\begin{array}{l}\text { CD8 + T } \\
\text { lymphocytes (\%) }\end{array}$ & $\begin{array}{l}36.4 \\
(6.0)\end{array}$ & $\begin{array}{l}36.2 \\
(6.6)\end{array}$ & $\begin{array}{l}39.6 \\
(6.7)\end{array}$ & $\begin{array}{l}33.8 \\
(8.6)\end{array}$ & $\begin{array}{l}38.5 \\
(9.2)\end{array}$ \\
\hline CD4: CD8 ratio & $\begin{array}{c}1.61 \\
(0.53)\end{array}$ & $\begin{array}{c}1.66 \\
(0.43)\end{array}$ & $\begin{array}{c}1.44 \\
(0.44)\end{array}$ & $\begin{array}{c}2.01 \\
(0.86)\end{array}$ & $\begin{array}{r}1.69^{\mathrm{a}} \\
(0.65)\end{array}$ \\
\hline $\begin{array}{l}\text { HLA-DR + CD3 + } \\
\text { T lymphocytes (\%) }\end{array}$ & $\begin{array}{c}6.1 \\
(1.9)\end{array}$ & $\begin{array}{l}7.1 \\
(4.0)\end{array}$ & $\begin{array}{r}7.8^{\mathrm{a}} \\
(3.4)\end{array}$ & $\begin{array}{l}10.1 \\
(4.7)\end{array}$ & $\begin{array}{l}10.4 \\
(5.1)\end{array}$ \\
\hline $\begin{array}{l}\text { HLA-DR + CD4 + } \\
\text { T lymphocytes (\%) }\end{array}$ & $\begin{array}{c}7.1 \\
(2.2)\end{array}$ & $\begin{array}{r}9.1^{b} \\
(2.4)\end{array}$ & $\begin{array}{r}8.6^{\mathrm{a}} \\
(2.6)\end{array}$ & $\begin{array}{c}8.1 \\
(2.5)\end{array}$ & $\begin{array}{l}11.0^{\mathrm{b}} \\
(3.8)\end{array}$ \\
\hline $\begin{array}{l}\text { HLA-DR + CD8 + } \\
\text { T lymphocytes }(\%)\end{array}$ & $\begin{array}{l}10.9 \\
(7.3)\end{array}$ & $\begin{array}{l}11.4 \\
(8.4)\end{array}$ & $\begin{array}{l}13.0 \\
(7.2)\end{array}$ & $\begin{array}{l}13.9 \\
(8.1)\end{array}$ & $\begin{array}{c}17.8 \\
(10.0)\end{array}$ \\
\hline
\end{tabular}

${ }^{\mathrm{a}} p<0.05,{ }^{\mathrm{b}} p<0.01$ when compared with appropriate control group

(JDF) units and correlation of observed with consensus JDF units of 0.74 . Results are reported here as positive or negative. Non-organ-specific autoantibodies (anti-nuclear (ANA), antismooth muscle (SMA), anti-gastric parietal cell (GPC), anti-mitochondrial (AMA) and anti-reticulin (ARA) antibodies) were detected by a similar technique using rat liver, kidney and stomach as substrate [24]. Autoantibodies reacting with thyroid microsomal antigens and with thyroglobulin were detected by particle agglutination using commerically available kits (Serodia-ATG, Serodia-ACM; Fujirebio, Tokyo, Japan).

\section{Statistical analysis}

Lymphocyte subsets were normally distributed according to the Kolmogorov-Smirnov goodness of fit test and mean values were compared using a one way analysis of variance and Student's $t$ tests. Results were considered significant if $p$ was less than 0.05 . In view of the smaller numbers and large variances, comparisons of variables between groups divided according to the presence or absence of autoantibodies and HLA DR types were performed using the non-parametric Mann-Whitney U-test. Comparison of the frequencies of autoantibodies occurring with different HLA alleles was performed using the Fisher's exact prob- 
ability test. Correlations between variables were analysed by calculating Pearson's correlation coefficient or performing Spearman's rank correlation tests as appropriate. Statistical computations were performed using the Statistical Package for the Social Sciences on the University of London Computer Centre's Amdahl 5980/300.

\section{Results}

Total, $C D 3+, C D 4+$ and $C D 8+$ lymphocyte subsets

The mean concentration of total lymphocytes was significantly reduced in children with Type 1 diabetes compared with control subjects ( $p<0.05$; Table 2$)$. Nondiabetic siblings had levels of total lymphocytes similar to the mean concentration in the diabetic children but not significantly different from control subjects. The mean concentration of total lymphocytes in the parents was similar to that of the adult control group.

The percentage and absolute number of $\mathrm{CD} 3+$ T lymphocytes were significantly lower in parents of children with Type 1 diabetes compared with control subjects ( $p<0.01$ and $p<0.05$, respectively), but normal in the diabetic children and their siblings.

Percentages of CD4 + T lymphocytes were similar in all study groups compared with control subjects. The absolute number of circulating CD4 + T lymphocytes was significantly lower in the siblings $(p<0.05)$ when compared with the appropriate control subjects. Percentages and absolute numbers of CD $8+$ lymphocytes were similar in all study groups compared with the appropriate control subjects. The $\mathrm{CD} 4: \mathrm{CD} 8$ ratio was not significantly different in diabetic children and their siblings compared with control subjects. The CD4:CD8 ratio was significantly reduced in the parents compared with control subjects $(p<0.05)$.

Total, CD3 +, CD4 + and CD8 + lymphocyte populations were similar in the diabetic children and their siblings.

\section{$H L A-D R$ expression on $C D 3+, C D 4+$ and $C D 8+$ Tlymphocytes}

Levels of activated (HLA-DR + ) CD3 + T lymphocytes were significantly elevated in the group of siblings compared with control subjects $(p<0.05)$ (Table 2). Mean levels of activated T lymphocytes in children with Type 1 diabetes and their parents were not significantly different from those of the appropriate control group.

The percentage of CD4 + T lymphocytes which was HLA-DR + was significantly higher in the diabetic children $(p<0.01)$, their siblings $(p<0.05)$ and their parents $(p<0.01)$ compared with the control subjects. The percentage of CD8 + T lymphocytes which was activated was similar in the diabetic children and their siblings compared with the control subjects.
Activated CD3 +, CD4 + and CD8 + lymphocytes were similar in the diabetic children and their siblings.

\section{$C D 45 R A$ and $C D 45 R O$ expression and $C D 4+$ Tlymphocytes}

Expression of the CD45R isoforms RA and RO can be divided into three groupings. Firstly, a CD45R isoform may occur alone on a cell (i.e. CD45RA + ROand CD45RA-RO + cells). Secondly, double-positive, CD45RA + RO + cells may be detected, representing a transition state from expression of one isoform to the other. Finally, CD45R isoform expression may be represented by the total CD45RA + (CD45RA + RO- plus CD45RA + RO + ) and total CD45RO + (CD45RA-RO + plus CD45RA + RO + ) cells.

In analysing these results a clear pattern of abnormal distribution of CD45 isoforms in diabetic children and their siblings was apparent, in favour of a relative over-expression of CD45RO and under-expression of CD45RA.

Levels of CD45RA + RO- CD4 + T lymphocytes were significantly reduced in the diabetic children and their siblings compared with control subjects $(p<0.01$ for both) (Table 3). In contrast, levels of CD45RA$\mathrm{RO}+\mathrm{CD} 4+$ lymphocytes were significantly elevated in diabetic children and their siblings compared with control subjects $(p<0.01$ for both). Levels of CD45RA + RO + CD4 + lymphocytes were similar in diabetic children, siblings and control subjects. As a result, total CD45RA + CD4 + lymphocytes were significantly lower and total CD45RO + CD4 + lymphocytes significantly higher in diabetic children $(p<0.01$ and $p<0.05$, respectively) and their siblings ( $p<0.001$ and $p<0.01$, respectively) compared with the control subjects. These findings are reflected in the ratio of CD45RA: RO amongst the CD4 + lymphocyte population, which was significantly reduced in diabetic children and their siblings compared with control subjects $(p<0.05$ and $p<0.01$, respectively). Amongst the siblings, there was no evidence of clustering of low or high levels of cells expressing particular CD45R isoforms in individual families. In the healthy children, levels of CD45RA + RO- CD4 + lymphocytes declined with age $(r=-0.54, p<0.01)$, but no relationship between age and CD45R subsets was seen in the study groups.

Levels of CD45 subsets and the CD45RA: RO ratio amongst $\mathrm{CD} 4+$ lymphocytes were similar in the diabetic children and their siblings and were similar in the parents of the diabetic children compared with the control group. 
Table 3. Mean (SD) percentages of CD45RA + and CD45RO + CD4 + T lymphocyte subsets in patients with Type 1 diabetes, their parents, siblings and control subjects

\begin{tabular}{|c|c|c|c|c|c|}
\hline & Normal children & $\begin{array}{l}\text { Type } 1 \text { diabetic } \\
\text { children }\end{array}$ & $\begin{array}{l}\text { Siblings of diabetic } \\
\text { children }\end{array}$ & $\begin{array}{l}\text { Adult control } \\
\text { subjects }\end{array}$ & $\begin{array}{l}\text { Parents of dia- } \\
\text { betic children }\end{array}$ \\
\hline $\begin{array}{l}\text { CD45RA + RO- } \\
\text { CD4 + } \\
\text { T lymphocytes (\%) }\end{array}$ & $\begin{array}{c}59.3 \\
(12.3)\end{array}$ & $\begin{array}{r}47.9^{\mathrm{b}} \\
(13.5)\end{array}$ & $\begin{array}{l}44.6^{\mathrm{b}} \\
(12.8)\end{array}$ & $\begin{array}{l}30.6 \\
(11.4)\end{array}$ & $\begin{array}{c}34.2 \\
(14.4)\end{array}$ \\
\hline $\begin{array}{l}\text { CD45RA-RO + } \\
\text { CD4 + } \\
\text { T lymphocytes (\%) }\end{array}$ & $\begin{array}{c}29.0 \\
(11.3)\end{array}$ & $\begin{array}{r}38.3^{\mathrm{b}} \\
(10.1)\end{array}$ & $\begin{array}{r}41.7^{\mathrm{b}} \\
(10.9)\end{array}$ & $\begin{array}{c}52.6 \\
(13.1)\end{array}$ & $\begin{array}{c}52.1 \\
(14.6)\end{array}$ \\
\hline $\begin{array}{l}\text { CD45RA + RO + } \\
\text { CD4 + } \\
\text { T lymphocytes (\%) }\end{array}$ & $\begin{array}{l}10.6 \\
(7.3)\end{array}$ & $\begin{array}{l}10.0 \\
(7.4)\end{array}$ & $\begin{array}{c}9.3 \\
(4.8)\end{array}$ & $\begin{array}{l}14.2 \\
(6.5)\end{array}$ & $\begin{array}{l}11.2 \\
(9.2)\end{array}$ \\
\hline $\begin{array}{l}\text { Total CD45RA + } \\
\text { CD4 + } \\
\text { T lymphocytes (\%) }\end{array}$ & $\begin{array}{c}69.9 \\
(14.1)\end{array}$ & $\begin{array}{l}57.6^{\mathrm{b}} \\
(9.4)\end{array}$ & $\begin{array}{r}53.8^{\mathrm{c}} \\
(10.0)\end{array}$ & $\begin{array}{c}44.8 \\
(14.3)\end{array}$ & $\begin{array}{c}45.1 \\
(14.8)\end{array}$ \\
\hline $\begin{array}{l}\text { Total CD45RO + } \\
\text { CD4 + } \\
\text { T lymphocytes (\%) }\end{array}$ & $\begin{array}{l}39.6 \\
(9.6)\end{array}$ & $\begin{array}{r}48.0^{\mathrm{a}} \\
(14.2)\end{array}$ & $\begin{array}{r}50.4^{\mathrm{b}} \\
(12.4)\end{array}$ & $\begin{array}{c}66.9 \\
(12.0)\end{array}$ & $\begin{array}{c}63.4 \\
(14.1)\end{array}$ \\
\hline CD45RA: RO ratio & $\begin{array}{c}1.93 \\
(0.84)\end{array}$ & $\begin{array}{r}1.39^{\mathrm{a}} \\
(0.77)\end{array}$ & $\begin{array}{r}1.15^{\mathrm{b}} \\
(0.39)\end{array}$ & $\begin{array}{c}0.71 \\
(0.31)\end{array}$ & $\begin{array}{c}0.83 \\
(0.64)\end{array}$ \\
\hline
\end{tabular}

${ }^{\mathrm{a}} p<0.05,{ }^{\mathrm{b}} p<0.01$ and ${ }^{\mathrm{c}} p<0.001$ when compared with appropriate control group

$T C R-\gamma \delta+T$ lymphocytes and $C D 5+$ B lymphocytes

Levels of TCR- $\gamma \delta+$ T lymphocytes were not significantly different in diabetic children (mean $\pm \mathrm{SD}$; $5.7 \pm 2.5 \%)$ or their siblings $(6.0 \pm 3.4 \%)$ compared with the normal children $(6.5 \pm 2.5 \%)$, nor in their parents $(4.4 \pm 2.8 \%)$ wh an compared with the adult control group $(4.3 \pm 4.1 \%)$. Levels of CD5 + B lymphocytes were not significantly different in diabetic children (mean $\pm \mathrm{SD} ; 36.9 \pm 14.9 \%$ ) or their siblings $(31.2 \pm$ $14.1 \%)$ compared with the normal children $(30.4 \pm$ $11.2 \%)$, nor in their parents $(19.5 \pm 14.1 \%)$ when compared with the adult control group $(23.2 \pm 14.3 \%)$.

\section{Associations between lymphocyte subsets and islet cell antibodies}

Islet cell antibodies (ICA) were detected in 17 diabetic children $(55 \%), 4(12 \%)$ of the siblings and $2(4 \%)$ of the parents. Levels of total and activated CD3+, $\mathrm{CD} 4+$ and $\mathrm{CD} 8+\mathrm{T}$-cell subsets, TCR $-\gamma \delta+\mathrm{T}$ cells and CD5 + B lymphocytes were similar in ICA-negative and ICA-positive diabetic children, their siblings and parents.

Compared with their ICA-negative counterparts, diabetic children with ICA had lower levels of CD45RA + RO- (median (range) 48.9\% (22.3-65.1) vs $58.8 \% \quad(42.4-73.6) ; p<0.05)$, higher levels of CD45RA-RO + (41.4\% (26.4-58.2) vs $30.1 \%(16.2-$ 38.7); $p<0.005)$ and higher levels of total CD45RO + CD4 + lymphocytes (48.8\% (32.9-77.0) vs $34.9 \%$ $(18.6-47.5) ; p<0.005)$. Levels of total CD45RA + $\mathrm{CD} 4$ + lymphocytes were reduced in the ICA-positive diabetic children $(54.6 \%(40.9-71.7)$ vs $62.4 \%$ (44.680.9 )) but not significantly. The ratio of CD45RA:RO amongst CD4 + lymphocytes was significantly lower in the ICA-positive diabetic children $(1.17(0.61-2.17)$ vs $1.40(1.2-3.92) ; p<0.05)$. This pattern of increased CD45RO expression associated with ICA was not seen in the siblings or parents of the diabetic children.

Siblings who were ICA positive had similar levels of the CD45RA : $R O$ ratio compared with those who were ICA negative.

\section{Associations between lymphocyte subsets and other autoantibodies}

Autoantibodies other than ICA were detected in 6 diabetic children (19\%), 8 siblings $(24 \%)$ and 15 parents $(29 \%)$. In one diabetic child, four siblings and six parents more than one autoantibody was present, usually as a combination of gastric parietal cell antibody and thyroid microsomal antibody which accounted for six of the cases of multiple autoantibodies.

Levels of total and activated CD3,$+ \mathrm{CD} 4+$ and CD8 + T-cell subsets, TCR- $\gamma \delta+\mathrm{T}$ cells and CD45RA/ CD45RO subsets of CD4 + lymphocytes were similar in groups of diabetic children divided according to the presence or absence of one or more of the non-ICA autoantibodies.

In contrast, when siblings were divided according to the presence or absence of all non-ICA autoantibodies, level of HLA-DR + CD3 + T lymphocytes were significantly lower in the autoantibody-positive group (median (range); $5.2 \%(3.5-8.1)$ vs $7.5 \%$ (3.5-16.8); 
Table 4. Levels of CD4 + and CD8 + T lymphocytes in siblings and parents of diabetic children divided according to possession of at least one DR4 or DR3 allele

\begin{tabular}{|c|c|c|c|c|}
\hline & & DR4 & DR3 & DR4 vs DR3 ( $p$ value) \\
\hline \multirow[t]{3}{*}{ Siblings of diabetic children } & & $(n=6)$ & $(n=12)$ & \\
\hline & CD4 $+\mathrm{T}$ cells $(\%)$ & $\begin{array}{l}43.6^{\mathrm{b}} \\
(39.8-54.4)\end{array}$ & $\begin{array}{l}59.7 \\
(43.0-67.3)\end{array}$ & $<0.05$ \\
\hline & CD8 $+\mathrm{T}$ cells $(\%)$ & $\begin{array}{l}51.9^{c} \\
(37.3-53.6)\end{array}$ & $\begin{array}{l}36.5 \\
(24.2-49.7)\end{array}$ & $<0.05$ \\
\hline \multirow[t]{3}{*}{ Parents of diabetic children } & & $(n=12)$ & $(n=18)$ & \\
\hline & CD $4+\mathrm{T}$ cells $(\%)$ & $\begin{array}{l}48.5^{c} \\
(33.3-59.4)\end{array}$ & $\begin{array}{l}62.0 \\
(47.3-70.3)\end{array}$ & $<0.01$ \\
\hline & CD8 $+\mathrm{T}$ cells $(\%)$ & $\begin{array}{l}46.2^{\mathrm{a}} \\
(28.2-66.0)\end{array}$ & $\begin{array}{l}35.8 \\
(23.1-54.7)\end{array}$ & $<0.05$ \\
\hline
\end{tabular}

${ }^{\mathrm{a}} p<0.05,{ }^{\mathrm{b}} p<0.01,{ }^{\mathrm{c}} p<0.005$ vs values in appropriate control subjects (see Table 1 )

$p<0.05$ ), whilst other T-lymphocyte subsets were similar in the two groups.

In the parents, percentage levels of CD8 + lymphocytes were significantly lower in the autoantibody-positive group (30.8\% (23.1-54.7)) compared with those who were autoantibody negative (38.1\% (30.5-66.0); $p<0.05)$. In addition, a significantly lower percentage of CD5 + B lymphocytes was found in autoantibodypositive parents, compared with those without circulating autoantibodies (11.6 (6.6-25.0) vs 17.1 (6.4-73.3); $p<0.05)$. Other lymphocyte subsets were similar in parents divided into groups according to the presence or absence of non-ICA autoantibodies.

\section{Associations betweeen lymphocyte subsets and HLA DR types}

In previous studies it has been shown that approximately $90 \%$ of children with Type 1 diabetes possess at least one DR3 or DR4 allele, and it is likely that any influence of class II loci on immune function in this disease would operate through these two genes. For this reason, and because of the small numbers in each study group, individuals were assigned to the following four groups: (i) possession of homozygous DR 3/3 or heterozygous DR3/X; (ii) heterozygous DR 3/4; (iii) homozygous DR $4 / 4$ or heterozygous DR4/X; and (iv) $\mathrm{DRX} / \mathrm{X}$ (where $\mathrm{X}$ is neither DR3 nor DR4).

Amongst the diabetic children, 7 (23\%) were DR3/3 or DR3/X, 13(42\%) were DR3/4, $9(29 \%)$ were DR $4 / 4$ or DR $4 / X$ and $2(6 \%)$ were DRX/X so that $94 \%$ of the diabetic children possessed at least one DR3 or DR4 allele. Amongst the siblings, 12 (35\%) were DR3/3 or DR3/X, $6(18 \%)$ were DR3/4, $6(18 \%)$ were DR4/4 or DR4/X, and $10(29 \%)$ were DRX/X. The frequency of certain haplotypes was different in the diabetic children compared with the siblings. A significantly higher proportion of the diabetic children were DR3/4 heterozygous (Fisher's exact probability $p=0.029$ ), whilst significantly more of the siblings pos- sessed alleles other than DR3 or DR4 (DRX/X; Fisher's exact probability $p=0.018$ ).

Amongst the diabetic children, there were no significant differences in levels of lymphocyte subsets between the four groups of class II haplotypes defined above.

Siblings with DR4/4 or DR4/X had significantly lower percentage levels of CD4 + lymphocytes and significantly higher percentage levels of CD8 + lymphocytes compared with those possessing DR $3 / 3$ or DR3/X and compared with control subjects (Table 4). This reduction of CD4 + lymphocytes and increase in CD8 + lymphocytes could not be attributed to clustering of low and high levels, respectively, in a small number of families, as shown by the individual values in Figure 1.

Three of the parents were not HLA typed. Of the remainder, $18(35 \%)$ were DR3/3 homozygous or DR3/X, 12 (23\%) were DR3/4 heterozygous, 12 (23\%) were DR4/4 or DR4/X and $10(18 \%)$ were $\mathrm{DRX} / \mathrm{X}$. The abnormality seen in the siblings was also seen in the parents (Table 4). Parents with DR4/4 or DR4/X had significantly lower percentage levels of CD4+ lymphocytes and significantly higher percentages of CD $8+$ lymphocytes compared with those with DR3/3 or DR3/X and compared with control subjects. In addition, levels of CD4 + lymphocytes were also significantly lower in DR4/4 and DR4/X parents and levels of CD8 + lymphocytes significantly higher compared with parents who were DR3/4 heterozygotes (\% CD4, $60.1 \%$ (48.1-73.1); \% CD8, 36.2\% (26.3-46.5); $p<$ 0.05 for both), suggesting that the DR3 allele has the strongest influence on determining high levels of CD4 + and low levels of CD8 + lymphocytes. Again, the DR4-associated reduction in CD4 + lymphocytes and increase in CD8 + lymphocytes could not be attributed to clustering of low and high levels, respectively, in a small number of families, as shown by the individual values in Figure 1.

To examine a possible genetic influence on CD4: CD8 ratio more closely, evidence of co-segregation of a low ratio with DR types was sought. In 


\section{\% CD4 lymphocytes}

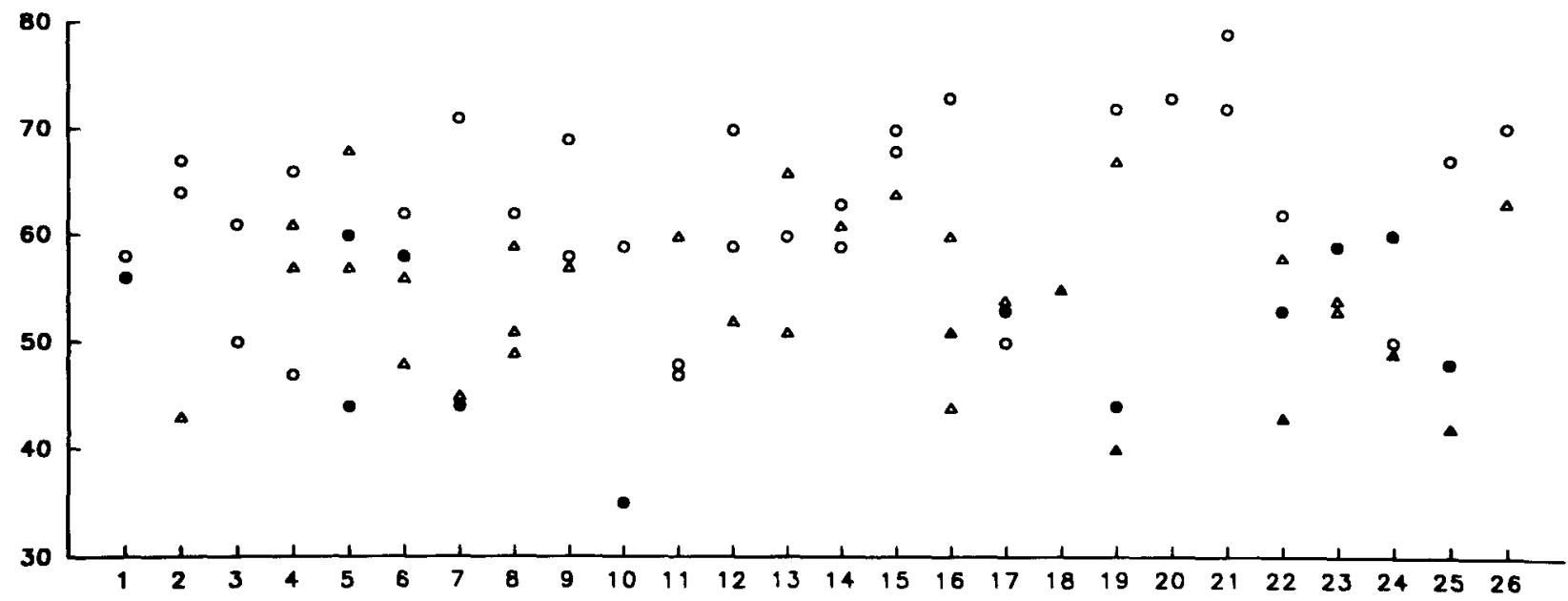

a

\section{Families}

\%CD8 lymphocytes

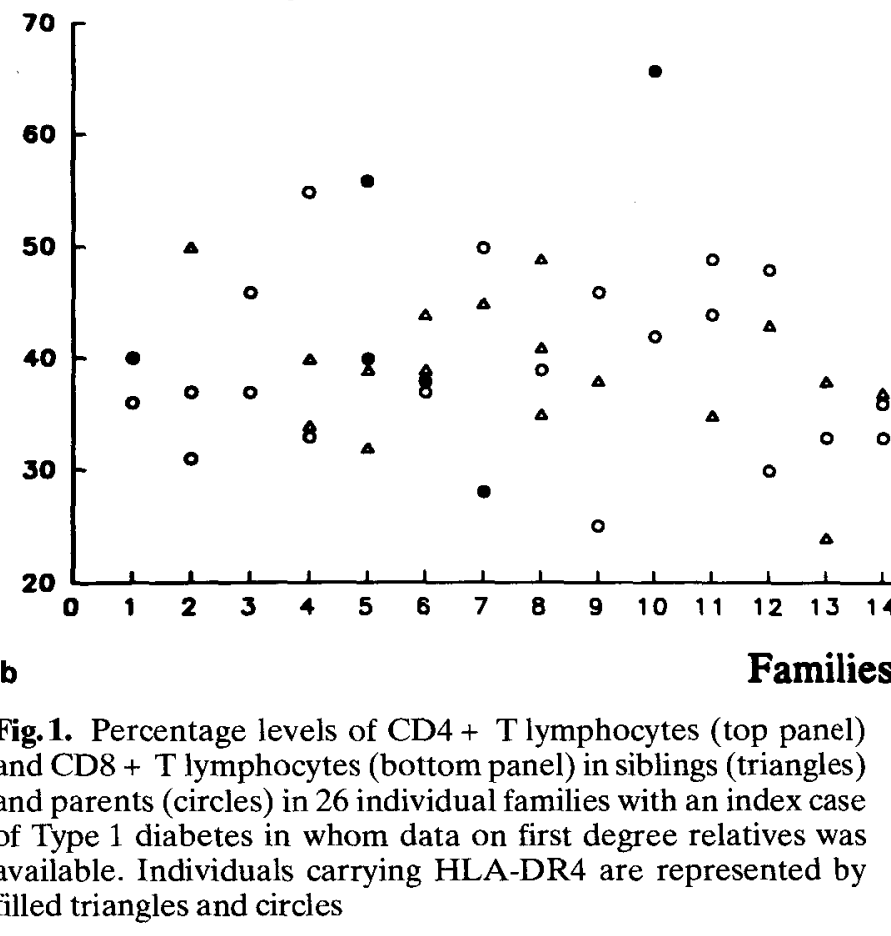

filled triangles and circles

11 families, ratios lower than the control mean in siblings segregated with a maternal or paternal haplotype, but no particular DR type was identified. Equally, no consistent pattern of alteration in CD4:CD8 ratio was shared by haploidentical siblings.

There was no evidence that siblings with the heterozygous HLA DR3/4 type or those sharing HLA identity with the index case had altered CD45RA:RO ratios in comparison with the remaining siblings.
Association between lymphocyte subsets, metabolic control and duration of diabetes

Amongst the diabetic children there was no relationship between the major functional $\mathrm{T}$-cell subsets, CD45R subsets of CD4 + T lymphocytes or CD5 + $B$ cells and random blood glucose, $\mathrm{HbA}_{1 \mathrm{c}}$, or duration of diabetes. A positive correlation between the percentage of HLA-DR + CD3 + T lymphocytes, the percentage of HLA-DR + CD8 T lymphocytes and level of $\mathrm{HbA}_{1 \mathrm{c}}$ was seen $(r=0.43$ and $r=0.42$, respectively; $p<0.05)$.

To further examine the influence of metabolic control on lymphocyte subsets, children with Type 1 diabetes were divided into those with $\mathrm{HbA}_{1 \mathrm{c}}$ levels less than 10.0 and those more than $10.0 \%$, with 15 and 16 children in each group, respectively. Compared with control subjects, diabetic children with worse metabolic control had significantly reduced total lymphocyte concentrations (mean $\pm \mathrm{SD} ; 2.4 \pm 0.6 \times 10^{6} / \mathrm{ml}$, 
$p<0.01$ ), whilst these were normal in the children with better control. Percentage levels of CD4+ HLA$\mathrm{DR}+\mathrm{T}$ cells were significantly elevated in both groups of diabetic children ( $p<0.01$ for both), indicating that this abnormality is not influenced by glycaemic control. As one might expect from the correlation between CD8 + HLA-DR + T cells and $\mathrm{HbA}_{1 \mathrm{c}}$, significantly reduced levels of these cells were found in the better controlled diabetic children compared with control subjects $(9.1 \pm 4.5 \%, p<0.01)$ but normal levels in the patients with $\mathrm{HbA}_{1 \mathrm{c}}$ greater than $10.0 \%$. None of the other immune parameters behaved differently in the two groups of diabetic children compared with the control subjects.

\section{Associations between autoantibodies and HLA DR types}

The presence of the autoantibodies ICA, ANA, SMA, ARA and AMA, GPC, TMA and TGA, analysed individually or as groups of non-organ and organ-specific autoantibodies, was not associated with any particular HLA DR type in diabetic children or their siblings. The same was true for their parents, with the exception of autoantibodies to thyroid microsomes or thyroglobulin, or both which were more frequently found in individuals with the haplotype DR3/3 or $3 / \mathrm{X}(40 \%)$ than in those with DR $4 / 4$ or $4 / \mathrm{X}(0 \% ; p=0.04)$.

\section{Discussion}

We have shown that abnormalities of lymphocyte phenotypic markers of function and activation are present in non-diabetic first degree relatives of children with Type 1 diabetes, as well as in the diabetic children themselves. The absolute number of CD4 + lymphocytes was significantly reduced in siblings of diabetic children. Levels of activated $T$ lymphocytes were elevated in siblings and there was an increase in activated CD4 + T lymphocytes in all family members. Over-expression of the memory-cell marker CD45RO and a reciprocal reduction in expression of the CD45RA marker of naive cells was detected in both diabetic children and their siblings, and amongst the former, was more marked in those with ICA. Finally, possession of HLADR4 appears to influence peripheral blood lymphocytes, since its presence was associated with reduced percentages of $\mathrm{CD} 4+$ and increased percentages of CD8 + cells in both siblings and parents of diabetic children.

There have been few previous studies of lymphocyte subsets in children with diabetes of several years duration. Results obtained in the present study for the main $\mathrm{CD} 3+, \mathrm{CD} 4+$ and CD8 + populations are similar to those of Pontesilli et al. [25] who also used a lysed whole blood technique and found a mild lymphopaenia and reduced percentages of $\mathrm{CD} 3+$ and $\mathrm{CD} 4+1 \mathrm{ym}-$ phocytes, but also low levels of CD8 + lymphocytes. Studying twins with diabetes of several years duration, Johnston et al. [26] found reduced levels of total $\mathrm{T}$ and CD4 + lymphocytes, as well as reduced CD8 + lymphocytes, as did Galluzzo et al. [27] and Quiniou-Debrie et al. [28]. The finding of reduced CD8 + lymphocytes in these studies but not our own may reflect a different approach to quantifying CD8 + cells, which in this study were simultaneously identified as T lymphocytes by double staining with antibodies to CD3. Staining with a single antibody, as in the other studies cited, would include the sizeable proportion of CD8 + lymphocytes which do not express CD3 [29], and this may be the population which is altered in diabetes.

Our data indicate reduced levels of absolute numbers of CD4 + lymphocytes in the siblings of diabetic children, and a reduced CD4:CD8 ratio in the siblings and parents, suggesting an inherited abnormality. Some evidence to support this derives from analysis of the HLA DR types, which identifies an association between possession of the HLA-DR4 allele and low percentage levels of CD4 + and reciprocally high levels of CD8 + lymphocytes in siblings and parents, compared with non-DR4 siblings and with control subjects. Evidence of co-segregation of low CD4:CD8 ratio and particular HLA-DR types was not found, possibly due to the relatively small number of families studied. DR3/4 heterozygotes had levels of CD4 + and CD8 + $T$ lymphocytes similar to siblings and parents with DR3 alone, suggesting that possession of DR3 can outweigh the influence of DR4 on these T-cell subsets. The presence of individuals possessing HLA DR4 could thus account for the low levels of CD4 + lymphocytes seen in these study groups. The numbers of diabetic children, siblings and parents with DR4 are small, however, and such a finding requires confirmation in a larger group. In addition, our data do not demonstrate whether or not the association is confined to families with an index case of diabetes or applies to DR4 in the general population, since our control subjects were not HLA typed. It is of interest that the association between the imbalance in CD4 + and CD8 + lymphocytes and possession of HLA-DR4 was not seen in the diabetic children. Since the mean duration of diabetes was more than 3 years and all children were treated with insulin it is possible that chronic hyperglycaemia or exogenous insulin, both of which are known to be capable of affecting immune function [30, 31], have exerted an effect in elevating CD4 + and depressing CD8 + lymphocyte levels in these patients partially overriding the effects seen in the siblings and parents.

Elevated levels of activated (HLA-DR +) T lymphocytes are a consistent finding in studies of patients with Type 1 diabetes near to the time of diagnosis [5, 32-34]. Levels begin to decline 6 months after diagnosis, and are normal in patients with long-term disease, unless diabetic complications are present $[35,36]$. 
Levels of activated total CD3 + T lymphocytes were normal in the children with Type 1 diabetes in the present study, yet the proportion of CD4 + T lymphocytes expressing HLA-DR was significantly elevated. This suggests that immune activation in Type 1 diabetes is ongoing, but is largely confined to the CD4 + subset and may not be revealed by analysis of total $T$ lymphocytes. Elevated levels of activated total $\mathrm{T}$ cells were found in the siblings, and an increased proportion of $\mathrm{CD} 4+$ lymphocytes which were activated were detected in siblings and parents. Siblings of children with Type 1 diabetes, despite often sharing the environmental and genetic risk of diabetes with the diabetic members of their family, have a relatively low risk of developing the disease themselves [37]. Activated T lymphocytes in siblings in this study are therefore unlikely to represent impending diabetes. The presence of a high proportion of activated CD4 + lymphocytes in siblings, parents and the diabetic children may represent the presence of a hyperactive immune system. Such a state has been previously invoked as a possible predisposing factor to autoimmune diseases in individuals with the haplotype A1 B8 DR3, who have impaired Fc receptor function [38] and impaired suppressor-cell function [39]. This hypothesis proposes that on this background, an environmental stimulus, such as a virus infection, could invoke an inappropriately vigorous immune response, in which damage to other host tissues is also incurred.

In a previous study, we described an over-representation of CD45RO on CD4 + lymphocytes in patients with long-term Type 1 diabetes, a finding confirmed in the present study [7]. The cell surface antigen CD45 has several isoforms and the presence of two of these phenotypes, CD45RA and CD45RO, appears to have a direct bearing upon the functional properties of the lymphocytes expressing them. CD45RA + ROcells are "virgin", or immunologically naive cells present at high levels in the fetus [40], and which, upon stimulation, begin to acquire the CD45RO marker of "primed" or memory cells [41]. Functionally, naive cells are unresponsive to antigenic stimulation and suppress other lymphocyte responses, whilst memory cells make appropriate proliferative responses and promote other lymphocyte responses such as antibody production by B lymphocytes. Several studies of the RA and RO isoforms of CD45 have been performed in chronic autoimmune diseases, indicating an expansion of the CD45RO subset of CD4 + lymphocytes in multiple sclerosis [42] and systemic lupus erythematosus [43]. In contrast, in patients analysed soon after the onset of Type 1 diabetes a relative over-expression of CD45RA is found $[7,44]$. Our present findings are consistent with both diabetic children and unaffected siblings being exposed to environmental stimuli which results in changes in immunoregulatory lymphocytes. Siblings who do not become diabetic are characterised by a preponderance of CD45RO lymphocytes in comparison with healthy children and are thus immunologically "primed". These results are in keeping with those of Schat $z$ et al. [45], who found that levels of memory cells were higher and naive cells lower in a group of subjects including low-risk, ICA-negative first degree relatives. Faustman et al. [46] investigated low-risk first degree relatives and failed to detect these abnormalities, but in their study memory cells were identified using antibodies directed against CDw29, which is known to be less powerful at discriminating this population than CD45RO [47]. Whether or not the primed immune system is protective against the development of diabetes is not known, but this possibility is supported by studies in the non-obese diabetic mouse and $\mathrm{BB}$ rat animal models of Type 1 diabetes, in which mice delivered by Caesarean section and reared in pathogen-free environments have a higher incidence of diabetes than those reared unprotected $[48,49]$. Alternatively, the presence of an excess of primed CD45RO + lymphocytes could be the result of an appropriate immune response to environmental agents involved in the aetiology of Type 1 diabetes.

In summary, we describe abnormalities of immunoregulatory lymphocyte subsets and activated helper $\mathrm{T}$ cells in first degree relatives of children with Type 1 diabetes. Some of the differences between the study groups and control subjects are small, and will require confirmation in larger studies. The finding, however, that similar patterns of abnormality are frequently present in diabetic children, siblings and parents supports our conclusions. Some of the abnormalities of lymphocyte subsets may be influenced by the HLA system, and could represent one component of the susceptibility conferred by inheritance of particular alleles. In addition, we extend our understanding of the relationship of CD45 isoforms to autoimmune disease, and suggest that primed lymphocytes could provide protection from Type 1 diabetes.

Acknowledgements. Dr. M.Peakman was a Wellcome Trust Research Training Fellow during this study. This work was supported by the Wellcome Trust. Dr. G. McNab is supported by the British Diabetic Association. We are grateful to Drs. K. Brown, C. Darby and S. Ng for their co-operation in these studies, as well as to the families who participated and to the children of the Medway and Gillingham Branch (Kent) of the Children's Liver Disease Foundation.

\section{References}

1. Bottazzo GF, Dean BM, McNally JM, Mackay EH, Swift PGF, Gamble R (1985) In situ characterization of autoimmune phenomena and expression of HLA molecules in the pancreas in diabetic insulitis. N Engl J Med 313: 353-360

2. Sibley RK, Sutherland DER, Goetz F, Michael AF (1985) Recurrent diabetes mellitus in the pancreas iso and allograft. A light and electron microscopic and immunohistochemical analysis of four cases. Lab Invest 53: 132-144

3. Leslie RDG, Lazarus NR, Vergani D (1989) Aetiology of insulin dependent diabetes. Br Med Bull 45: 58-72 
4. Drell DW, Notkins AL (1987) Multiple immunological abnormalities in patients with type 1 (insulin-dependent) diabetes mellitus. Diabetologia 30: 132-143

5. Alviggi L, Johnston C, Hoskins PJ et al. (1984) Pathogenesis of insulin dependent diabetes: a role for activated $\mathrm{T}$ lymphocytes. Lancet II: 4-5

6. Muñoz A, Gallart T, Viñas O, Gomis R (1991) Increased CD5-positive B lymphocytes in type I diabetes. Clin Exp Immunol 83: 304-308

7. Smerdon RA, Peakman M, Hussain MJ et al. (1993) Increase in simultaneous co-expression of naive and memory markers at diagnosis of insulin dependent diabetes mellitus. Diabetes 42: $127-133$

8. Peakman M, Vergani D (1992) Cell mediated immunity and type 1 diabetes. Diabetes Rev 1: 5-8

9. Todd JA (1990) Genetic control of autoimmunity in type 1 diabetes. Immunol Today 11: 122-128

10. Todd JA, Bell JI, McDevitt HO (1987) HLA-DQ beta gene contributes to susceptibility and resistance to insulin-dependent diabetes mellitus. Nature 329: 599-604

11. Khalil I, D' Auriol L, Gobet Met al. (1990) A combination of HLA-DQ $\beta$ Asp57-negative and HLA DQ $\alpha$ Arg52 confers susceptibility to insulin-dependent diabetes mellitus. J Clin Invest 85: 1315-1319

12. Wen L, Peakman M, Lobo-Yeo A et al. (1991) T-cell-directed hepatocyte damage in autoimmune chronic active hepatitis. Lancet 336: $1527-1530$

13. Van Vliet E, Roep VO, Meulenbroek L, Bruining GJ, De Vries RRP (1989) Human T cell clones with specificity for insulinoma cell antigens. Eur J Immunol 19: 213-216

14. Roep BO, Aarden SD, De Vries RRP, Hutton JC (1990) Tcell clones from a type-1 diabetes patient respond to insulin secretory granule proteins. Nature 345: 632-634

15. Altmann DM, Sansom D, Marsh SGE (1991) What is the basis for HLA-DQ associations with autoimmune disease? Immunol Today 12: 267-270

16. National Diabetes Data Group (1979) Classification and diagnosis of diabetes mellitus and other categories of glucose intolerance. Diabetes 28: 1039-1057

17. Peakman M, Tredger JM, Davies ET, Davenport M, Williams R, Vergani D (1993) Analysis of peripheral blood mononuclear cells in rodents by 3-colour flow cytometry using a small-volume lysed whole blood technique. J Immunol Methods 158: 87-94

18. Peakman M, Buggins A, Nicolaides K, Layton DM, Vergani D (1992) Analysis of lymphocyte phenotypes in cord blood from early gestation foetuses. Clin Exp Immunol 90: 345350

19. Doherty DG, Donaldson PT (1991) HLA-DRB and DQB typing by a combination of serology, retriction fragment length polymorphism analysis and oligonucleotide probing. Eur J Immunogenet 18: 111-124

20. Bidwell JL, Jarrold EA (1986) HLA-DR allogenotyping using exon-specific cDNA probes and application of rapid minigel methods. Mol Immunol 23: 1111-1116

21. Bidwell JL, Bidwell EA, Savage DA, Middleton D, Klouda PT, Bradley BA (1988) A DNA-RFLP typing system that positively identifies serologically well-defined and ill-defined HLA-DR and DQ alleles, including DRw10. Transplantation 45: 640-646

22. Bidwell JL (1988) DNA-RFLP analysis and genotyping of HLA-DR and DQ antigens. Immunol Today 9: 18-23

23. Millward BA, Hussain MJ, Peakman M, Pyke DA, Leslie RDG, Vergani D (1988) Characterization of islet cell antibody in insulin dependent diabetes: evidence for IgG1 subclass restriction and polyclonality. Clin Exp Immunol 71: 353-356
24. Peakman M, Lobo-Yeo A, Mieli-Vergani G, Davies ET, Mowat AP, Vergani D (1987) Characterization of anti-liver kidney microsomal antibody in childhood autoimmune chronic active hepatitis: evidence for IgG1 subclass restriction, polyclonality and non-cross reactivity with hepatocyte surface antigens. Clin Exp Immunol 69: 543-549

25. Pontesilli O, Chase HP, Carotenuto P, Herberger MJ, Hayward AR (1982) T-lymphocyte subpopulations in insulin-dependent diabetes mellitus. Clin Exp Immunol 63: 68-72

26. Johnston C, Alviggi L, Millward BA, Leslie RDG, Pyke DA, Vergani D (1988) Alterations in T-lymphocyte subpopulations in type 1 diabetes: exploration of genetic influence in identical twins. Diabetes 37: 1484-1488

27. Galluzzo A, Giordano C, Rubino G, Bompiani GD (1984) Immunoregulatory T-lymphocyte subset deficiency in newly diagnosed type 1 (insulin-dependent) diabetes mellitus. Diabetologia 26: $426-430$

28. Quiniou-Debrie MC, Debray-Sachs M, Dardenne M, Czernichow P, Assan R, Bach JF (1985) Anti-islet cellular and humoral autoimmunity, T-cell subsets, and thymic function in type 1 diabetes. Diabetes 34: 373-379

29. Richards SJ, Scott CS (1990) Immunophenotypic dissection of normal peripheral blood NK-associated (NKa) subpopulations by flow cytometry: morphological features and relationships between NKa (CD11b, CD16, CD56 and CD57) and T-cell (CD2, CD3, TCR, CD5, CD7, CD8 and CD38) associated determinant expression. Leukemia Lymphoma 2: $111-126$

30. Selam JL, Clot J, Andary M, Mirouze J (1979) Circulating lymphocyte subpopulations in juvenile onset diabetes: a correction of abnormalities by adequate metabolic control. Diabetologia 16: $35-40$

31. Crosti JL, Secchi A, Ferrero E et al. (1986) Impairment of lymphocyte-suppressive system in recent-onset insulin dependent diabetes: correlation with metabolic control. Diabetes 35: 1053-1057

32. Pozzilli P, Zuccarini O, Iavicoli M et al. (1983) Monoclonal antibodies defined abnormalities of T-lymphocytes in type 1 (insulin-dependent) diabetes. Diabetes 32:91-94

33. Peakman M, Hussain MJ, MillwardBA, Leslie RDG, Vergani D (1990) Effect of initiation of insulin therapy on T-lymphocyte activation in type 1 diabetes. Diabetic Med 7:327-330

34. Jackson RA, Morris MA, Haynes BF, Eisenbarth GS (1982) Increased circulating Ia-antigen bearing $T$ cells in type $I$ diabetes mellitus. N Engl J Med 306: 785-788

35. Gilbey SG, Hussain MJ, Watkins PJ, Vergani D (1988) Cellmediated immunity and symptomatic diabetic autonomic neuropathy. Diabetic Med 5: 845-848

36. Bending JJ, Lobo-Yeo A, Vergani D, Viberti GC (1988) Proteinuria and activated $\mathrm{T}$ lymphocytes in diabetic neuropathy. Diabetes 37: 507-511

37. Allen C, Palta M, D' Allessio DJ (1991) Risk of diabetes in siblings and other relatives of IDDM subjects. Diabetes 40 : 831-836

38. Lawley TJ, Hall RP, Fauci AS, Katz SI, Hamburger MI, Frank MM (1981) Defective Fc-receptor functions associated with the HLA-B8/DRw3 haplotype: studies on patients with dermatitis herpetiformis and normal subjects. N Engl J Med 304: 185-192

39. Jaworski MA, Colle L, Guttmann RD (1983) Abnormal immunoregulation in patients with insulin dependent diabetes mellitus and their healthy first degree relatives. Hum Immunol 7: 25-34

40. Peakman M, Buggins AGS, Nicolaides KH, Layton DM, Vergani D (1992) Analysis of lymphocyte populations in cord blood from early gestation fetuses. Clin Exp Immunol 90: $345-350$ 
41. Beverley PCL (1990) Is T-cell memory maintained by crossreactive stimulation? Immunol Today 11:203-205

42. Morimoto C, Hafler DA, Weiner HL et al. (1987) Selective loss of the suppressor-inducer $\mathrm{T}$ cell subset in progressive multiple sclerosis: analysis with anti-2 $\mathrm{H} 4$ monoclonal antibody. N Engl J Med 316: 67-73

43. Morimoto C, Steinberg AD, Letvin NL et al. (1987) A defect of immunoregulatory $\mathrm{T}$ cell subsets in systemic lupus erythematosus patients demonstrated with anti-2 44 antibody. J Clin Invest 79: 762-763

44. Faustman D, Eisenbarth GS, Daley J, Breitmeyer J (1989) Abnormal T-lymphocyte subsets in type 1 diabetes. Diabetes 38: $1462-1468$

45. Schatz DA, Riley WJ, Maclaren NK, Barrett DJ (1991) Defective inducer T-cell function before the onset of insulin-dependent diabetes mellitus. J Autoimmunity 4: 125-136
46. Faustman D, Schoenfeld D, Ziegler R (1991) T-lymphocyte changes linked to autoantibodies: association of insulin autoantibodies with CD4 + CD45R + lymphocyte subpopulation in prediabetic subjects. Diabetes 40: 590-597

47. Sanders ME, Makgoba MW, Shaw S (1988) Human naive and memory T cells: reinterpretation of helper-inducer and suppressor-inducer subsets. Immunol Today 9: 195-199

48. Suzuki T, Yamada Y, Fujimura T et al. (1987) Diabetogenic effects of lymphocyte transfusion on the NOD or NOD nude mouse. In: Rygaard J, Brunner N, Graem N, Spang-Thomsen $\mathrm{M}$ (eds) Immune-deficient animals in biomedical research. Karger, Basel, pp 112-116

49. Like AA, Guberski DL, Butler L (1991) Influence of environmental viral agents on frequency and tempo of diabetes mellitus in BB/Wor rats. Diabetes 40: 259-262 